\title{
The Character Adaptation of Masked Puppet Figures in Ruwatan Ritual
}

\author{
Robby Hidajat \\ Department Dance and Music Education, Universitas Negeri Malang, Indonesia \\ Jl. Semarang No.5, Sumbersari, Kec. Lowokwaru, Kota Malang, Jawa Timur 65145 \\ ${ }^{\bowtie}$ E-mail: gantargumelar@gmail.com
}

Received: October 21, 2016. Revised: December 1, 2016. Accepted: December 11, 2016

\begin{abstract}
One myth that is believed by people living in Duwet village is distress that threatens human beings from when they are born till the day they die. As one way to overcome the distress, people, especially those who are living in Duwet village, hold ritual called as tolak bala. One step in the ritual is self-cleaning oneself from distress or sukerta. In addition to the ritual is a masked puppet as a means of the ritual execution. Thus, this study aims at finding out the functions of the Ruwatan masked puppet. Functional-structural perspective was adopted in the study by implementing observation, interview, and documentation study techniques. Results show that masked puppet has a special function which is to serve as a means of Ruwatan that is specifically to obtain society participation in order to give spiritual support to the process of ritual as a whole tolak bala or distress expulsion process.
\end{abstract}

Keywords: performing arts; masked puppet; ritual; character adaptation

How to Cite: Hidajat, R. (2016). The Character Adaptation of Masked Puppet Figures in Ruwatan Ritual. Harmonia: Journal of Arts Research and Education, 16(2), 192-201. doi:http:/ / dx.doi.org/10.15294/harmonia.v16i2.8783

\section{INTRODUCTION}

Duwet village society lives in a western part of Tengger mountain slope. The people of the village are generally Javanese, originated mainly from Malang regency. The people are usually known as 'arek' society as their daily attitude and personality are generally considered spontaneous and seemed harsh. The language they use is Javanese's Ngoko, the informal form of Javanese. From the mentioned characteristics, the society is often called as indigenous Javanese people, or countryman. However, even though common people address the society as a countryman or indigenous people, some public figures, including the puppeteers, belove that these Duwet societies belongs to the descendant of Mataram Kingdom (Interview, March
15, 2015).

As Javanese society in general, people in Duwet village also believe in Kejawen belief, spiritual, ethical, and moral beliefs hold by Javanese (Sunarto, 2009, p. 28). Therefore, several traditional rituals are still performed and preserved. Every once in a month, on Friday of Jumat Legi, Duwet village society visits their ancestors' cemetery (nyadran) and have a ritual named selamatan. Furthermore, the society also still believes in a good day and a bad day in holding an important event or ceremony as well as good luck and bad luck which depends on the day when a person is born. Rituals are then held to fix these bad luck problems caused by an unrelated day of birth which is categorized as sukerto. In order to avoid more problems or bad lucks, society performs the ritual of tolak balak 

(avoiding distress), popularly known as ruwatan.

Ruwatan as a Javanese tradition has become the Javanese society's belief since thirteenth to the fourteenth century. The evidence is relief carved in Tigawangi temple under the leadership of King Rajasawardhana in 1358. In the temple, Sudamala character was carved. The character of Sudamala was purposefully carved as a reminder of soul cleaning done by the only daughter of King Rajasawardhana and Bhre Lasem by doing ruwatan. According to the tradition, an only child has to be cleaned (diruwat) for safety purposes (Muljana, 1979, p. 264).

Ruwatan in this study is an ancient tradition of soul purification done by people who keep having bad luck or having life at stake because of the less-belated day of born (Rusdy, 2010, p. 23). This tradition is considerably common in Java, by using shadow puppet performance as a means to conduct the ritual. However, for people living in Western Malang Regency and Tengger, the masked puppet is used instead of the shadow one. Both puppet rituals, however, perform the story of Murwakala (laire batara kala).

The tolak balak ritual which is done by villagers living in Duwet village is categorized as a threat expulsion ritual to clean one's soul from the bad spirit which puts one's life in danger. This ritual is also used as a prayer ritual for the ancestors' spirits to give abundant blessings in the attempt of the society to repel the bad spirit (Sorjo, et al., 1985, p. 89).

When this study was done, a masked puppet dancer from Duwet village was eager to hold a ruwatan ritual for his daughter before she was married. The ritual gave the researcher an actual opportunity to conduct a direct observation to the ritual as well as the masked puppet performance.

In Malang Regency, masked puppet communities still exist in some places, i.e. Kedungmonggo Village in Pakisaji District, Glagahdowo and Jabung in Tumpang District, Jambuer and Jatiguwi in
Sumberpucung District, and Gunungkawi in Pujon District. From those districts, the community that still actively performs the masked puppet is Glagahdowo community in Tumpang District (Indrawati, 2009, p. 81). Until the 2000s, people in that community still held the masked puppet performance for the ruwatan ritual. The Masked Puppet Performing Art Group namely Asmarabangun from Tumpang District was often asked to perform the ruwatan ritual with a puppeteer named Rasimen (Interview, May, 2, 2015).

Ruwatan was also performed in every born day of a newborn baby. It was known as tumpak wayang. Interviewee 3 described his experience in performing masked puppet in the 1970s. Interviewee 3 was a puppeteer and had to perform the ritual of a newborn baby who was born on the day when the ritual was performed. The newborn baby was brought to the performance stage. Soon after the ritual, the puppeteer gave the baby a name and adopted him as his children. The phenomenon of giving names to the newborn baby by the puppeteer itself was common and was also done by puppeteers from Cirebon. A baby who got his name from the puppeteer during the performance was then called as the stage baby' (Suanda, 2009, p. 50).

Ruwatan ritual is considered as an important and main ritual. The ritual itself is generated from individual awareness, usually parents who consider their family member's bad luck, judging from their bad born day or bad behavior which cause the feeling of restlessness for the parents. There are special times when the ritual can be performed. For boys, it is when they have circumcision, while for a girl is when they are about to get married. During those times, the rituals are suggested to be done as the purpose of the ritual is for the individuals to do social reintegration which naturally brings social immunity (Kusmayati, 2013).

In addition, Ruwatan ritual is one way for the society in Kedungmangga Village to perform spiritual and mental condition purification for them to be free from 
danger and distress. If the ritual is held, an individual will be released or reborn and able to act normally as other people do.

\section{METHOD}

This study employed functionalstructural perspective (Poloma, 2010, p. 180). This perspective underlines the social structure and behavior aspects of an actor who does interactive action within a social process (Ritzer, 2009, p. 112). Data was collected by doing observation, interview, and documentation study. The interviewees in the study were interviewee 1 (a puppeteer, 64 years old) from Tumpang village, interviewee 2 (38 years old, the ruwatan organizer), and interviewee 3 (61 years old, the masked puppet music player specializing in kendang). The three of them were key informants in this study. Other interviewees were technical informants, interviewee 4 (43 years old, the leader of Masked Puppet Community Asmababangun from Kedungmangga Village), interviewee 5 (58 years old, a puppeteer of masked puppet from Sumberpucung), Interviewee 6 (66 years old, leader of Masked Puppet Wirabakti from Jabung Village), and Interviewee 7 (65 years old, a masked puppet puppeteer from Duwet village).

\section{RESULT AND DISCUSSION}

\section{Ruwatan Masked Puppet}

Ruwatan masked puppet is performed by an experienced puppeteer. The experienced puppeteer himself has to be one who has one or a married children, or is actually the descendant of a ruwatan puppeteer. Masked puppet in Malang regency is actually similar or refer to Shadow puppet puppeteers, like Rusman, Karimen, Kangsen, Rusnadi, Sanip, or Soleh Adi Pramana who perform using the story of murwakala, the story of the day when Batara Kala was born. However, each puppeteer also considers the technical aspects, whether the story of murwakala is told in a complete version (jankep), started from jêjêralangalang kumitir or awang-awang kumitir up to
Bhatarakala gives up his child to pray.

Ruwatan masked puppet with Moch Soleh Adipramana as the puppeteer is started with the scene of jejer kahyangan. It was told that Sanghyang Wenang had lived alone by himself without company. One day, Sanghyang Wenang meditated. He was then given two boys named Nurcahyo and Nurrasa. Both were given their special places. Nurcahyo stayed in the upper world, while Nurrasa stayed at the bottom world. Sometimes, they argued about who were older between them since it was not told when they were both created. When their debate was not going to be over, Sanghyang Wenang came to approach them. Both Nurcahyo and Nurasa were merged into one and named as Sanghyang Tunggal.

After Sanghyang Tunggal became the sole ruler of the universe, Sanghyang Tunggal then created its children and made them leaders of the universe. The eastern world or eastern universe was lived by Sanghyang Puguh, the northern part was lived by Sanghyang Jayawilapa, the western part was by Sanghyang Ismaya. From these four sons of Sanghyang Tunggal, a king should be chosen. There was no rule to choose the King. There has been just competition in finding $\mathrm{Cupu-}$ manik Astagina which was thrown to the eastern part. The three Sanghyangs were very enthusiast and left Sanghyang Ismaya behind because he had no ambition to be a King. Sanghyang Puguh, on the other hand, was very excited but failed to get the competition. Cupu Manik Astagina rolled by itself towards Sanghyang Manikmaya.

Sanghyang Puguh who had the ambition to have the cupu manik had a big fight with the cupu manik holder, Sanghyang Manikmaya. Both of the involved in a fight that pushed Sanghyang Puguh to use all his power. He then ate a small mountain called Waja till his mouth got wider and part of the mountain fell on Sanghyang Puguh's body. As a result, the body of Sanghyang Puguh turned into fat and small. Sanghyang puguh was sorry for what he did. But, everything had hap- 
pened and nothing could be changed. After that, Sanghyang Puguh was asked to go back to his origin in the eastern part of the world to be a guardian of the people living there. In this place, Sanghyang Puguh was given a new name, Togok Tejo Mantri. Besides Sanghyang Puguh, Sanghyang Jayawilopo also had fought against Sanghyang Manikmaya to get the cupu manik. Because of the fight, Sanghyang Jayawilopo was arrested by catching his head and back and was pulled till he could feel the pain. Even, his body was turned into a dragon. He was then known as the King of Dragon or Naga Raja and lived in the southern part of the world. His place was known as Kayangan Saptapratolo, the Kingdom of satan and gin.

Ismaya, on the other hand, who had no ambition to have cupu manik was forced by Manikmaya to have it. Manikmaya tortured him, hoping that he wanted to have the cupu manik. As a result, Ismaya's body became swollen. Knowing Ismaya's body condition, Sanghyang Tunggal gave him clothes and asked him to live in the western part of the universe known as Kayangan Klampis Iring to accompany and take care of Javanese knights and nobles. Ismaya was also given a new name that was Semar Badranaya.

In the end, Manikmaya who had had the cupu manik was asked to stay at Kayangan Jungring Salaka and entitled as King of Gods and Goddess. The new name given by his father was Bhatara Guru. After becoming the new king for a few days, Manikmaya wanted to have a spouse or company who could give him children. He wanted the world to have a new baby born after the love of the parents. After that, Manikmaya meditated and soon after that he pulled out his right ribs that turned into a baby and named the baby Sanghyang Umar. Sanghyang Umar was very handsome that made Manikmaya fell in love into him. But, because Both Manikmaya and Sanghayang Umar shared the same sex, Sanghayang Umar rejected the love and run far away from Manikmaya. Sanghyang Umar was caught soon after that and Manikmaya pulled out his genitals that turned into ular-ular (a tornado). Sanghyang Umar turned into a woman in a second and named as Batari Uma or Umayi. This became the beginning of the story of Murwakala (Suyanto, 2002, p. 67).

One day, Sanghyang Manikmaya saw a very dark cloud in the western part of the world. He went to the dark cloud and met a hermit in a place named Kedung Cingkrang. The hermit was asked but never answered. Manikmaya pissed off and kicked the hermit which led to a fierce battle with Manikmaya was out as a winner. After losing the fight, the hermit told Manikmaya that he wanted to be the King of nirvana. The willingness of the hermit became true after Manikmaya gave him a chance and named him Sanghyang Narada.

Sanghyang Manikmaya did not go back to the nirvana, or Kayangan, but he continued his journey to a place who was now known as the Bali island. This island was ruled by a cow named Andini. When Manikmaya came, Andini was preparing to attack Kayangan because she had a dream to become the King of every Gods and Goddess. Again, Manikmaya fought her and won it. Manikmaya, however, gave her a chance to rule Kayangan with him by using her as his official ride.

Soon after that, Jejer Kayangan, Sanghyang Manikmaya and Batari Uma rode Andini, who was a cow, to go around the universe. Unfortunately, in the middle of the journey, the desire of Sanghyang Manikmaya for sex rose and his sperm was taken by the tornado to the south ocean. The sperm fell into the ocean and was eaten by the Gangga fish causing her belly to grow and shine, causing the universe to shake.

Narada who was in Nirvana or Kayangan at that time felt worried and asked all Gods to go to the south ocean. They were asked to calm ocean. On the contrary, after arriving at the ocean, the chaos turned worse. The Gods threw their weapons to the fish. All of a sudden, a giant rose from the ocean and beat all the Gods.

It was told in the story that after bea- 
ting all the Gods, the giant then ran after the Gods. In the middle of his way, he stopped and confused because he had no idea who he was. During his uncertainty, he found a tree trunk. He kicked the trunk until there was a spirit out of the trunk and pissed at him by saying, "Kala, kurang ajar (Damn it, Kala)!". The giant was not mad but happy to hear that because he had finally had a new name, Ajar Kala.

Ajar Kala continued his journey to find his parents to the east. In the middle of his way, he was tired and mad then kicked a piece of stone and broke it into two separated parts. The stone is now known as Selo Mertangkep and still at its initial place in Ngersopada, the eastern part of Malang.

Ajar Kala was continuing his journey while he was finally captured by Deva Vishnu. Ajar Kala was broken into two pieces by Deva Vishnu, tied up and went down into Candradimuka crater. All of the weaponry had by the Gods was thrown into the crater as well, hoping that Ajar Kala would be destroyed faster. In fact, Ajar Kala was not destroyed and even grew stronger. He went after all Gods and not to mention to Deva Vishnu. Deva Vishnu ran all the way to save his life till Kayangan and met Sanghyang Manikmaya. On the other side of the universe, Ajar Kala met Narada along his way who finally told him everything about the sperm of Sanghyang Manikmaya story and how he was finally born. Hearing the story, Ajar Kala wanted to meet his father desperately. But, Narada did not let him go. Instead he gave Ajar Kala a pair of shoes and a set of Nirvana clothes for Ajar Kala to go seeing his father. Soon after that, Ajar Kala met Sanghyang Manikmaya and asked for a name and food from him. Manikmaya named him Batara Kala and gave him food. All food given to Batara Kala had to be cut by using special Nirvana weaponry called as Bedama. Bedama was actually Batara Kala's own tusk which was pulled out by Deva Vishnu when he beat Batara Kala earlier. Sanghyang Manikmaya also introduced Batara Kala to his mother, Bethari Uma.
Batari Uma also gave Batara Kala plenty of foods including all human who were walking alone at noon, baby who felt down from his mother's arm, and human who cooked rice but dropped the pan. This lets Sanghyang Manikmaya's anger and he turned Batari Uma into a giant known as Batari Durga. In masked puppet, she was known as Wadhal Werdhi (Interview, June 2 2012).

Bhatara Kala's habit to eat caused him to feel hungry easily. While starving, he went to a village and met Sanghyang Manikmaya there. Could not resist his starving, he held Sanghyang Manikmaya and was about to eat him, but Manikmaya was able to stop Batara Kala. Manikmaya told Batara Kala that he wanted to shower before he was eaten by Batara Kala. He wanted Batara Kala to eat the clean body of him. Batara Kala agreed to it and waited. When Manikmaya finished showering, the sun was in the west already that made his attempt to eat his father failed. He continued his journey, then (Interview, August 11, 2015).

Bhatara Kala arrived at a village where a masked puppet was performed. The puppeteer was Batara Vishnu with Bathara Kanakaputra (Narada) and Batara Brama as the music players. Before doing the rituals, an offering was placed in front of the stage. In the middle of a performance, Batara Kala was able to catch one of sukerta child, but the child ran and hide in the middle of the masked puppet performance. But because of the performance, Batara Kala could not get the child, instead he stopped, sat, and watched. Suddenly, the puppeteer stopped his performance and Batara Kala asked him why he stopped. The puppeteer told him that the performance had actually been over. It had finished. The puppeteer wanted to go home. Batara Kala wanted the puppeteer to continue his show, he did not want the puppeteer to stop. The puppeteer did not want to replay his performance without any fee. Then, Batara Kala gave him all golds and pearls from his Nirvana clother for the puppeteer, but it was rejected. A puppe- 
teer could not accept any golds nor pearls. In the end, Batara Kala gave the puppeteer his weapon, bedama, to the puppeteer, which was accepted.

While the show was on, the child who was Batara Kala's prey, showed up and caught by Batara Kala. But, when Batara Kala was about to have him, Batara Kala realized that he had not had his weapon with him, he had given the weapon to the puppeteer. He asked the puppeteer for his weapon but the puppeteer refused to give it back. Batara Kala was the son of a God, thus, all of his words could not be taken back.

The puppeteer gave Batara Kala choices. If Batara Kala wanted his weapon back, he could have it for once, but then he could not eat any more human because the puppeteer had the weapon with him. But, if Batara Kala wanted the puppeteer to return the weapon to him for good, he was not allowed to eat human forever. Batara Kala preferred the weapon and gave the child to the puppeteer. Soon after that, Batara Kala left after promising that he would never eat any more human, especially children. During the weapon-child switch, the atmosphere was tense and even the child passed out. The puppeteer gave the child a magic spell and spilled water to him for the child to be back to normal again (Interview, May 4, 2012).

Ki Dalang pangruwatan or the puppeteer is symbolized as the descendant of a ruwat puppeteer who generally has to perform lakutirakat, fasting, and avoiding taboo that may fail the worship or tirakat. This spiritual action is the basic ground to perform a ritual (Koentjaraningrat, 1981, p. 256). The host of ruwatan, in addition, also has to perform tirakat, and has to prepare all necessary errands for the ritual purposes. The lack of offering sometimes causes an obstacle to occur. The obstacle can be spirit possession, the mask which cannot be taken off, or heavy rain.

The story of Murwakala in the masked puppet ritual performance is an adaptation of another puppet story (wayang purwa) entitled The Born of Batara Kala and Murwakala.The are scenes called sabrang when the character of Raden Gunungsari is replaced with the character of Batara Kala and the character of Raden Guungsari is manifested as the character of Deva Vishnu or the puppeteer. It is examined closely, the aspect of adaptation is clearly seen. For instance, the character of Raden Gunungsari is the adaptation from character Deva Vishnu and the character of Kalana Sewandana is adapted to build the character of Batara Kala.

Three are aspects of the performance which are interesting to be studied as adaptation measures. First is the presentation structure of the masked puppet performance which belongs to the aspect of transmission. The transmission here is the bridge to relate the existence of Murwakala's story elements as an integrated part of a new form of puppet performance. Second is the existence of sabrang scene to build the character of Batara Kala under consideration of identical factor position which is the similarity nature of the character of keras (rough). Keras (rough) here can be interpreted as the opposite of alus (calm that in the puppet show presents the illustration of the human world and the spirit world.

Batara Kala belongs to the character performing sabrang scene is because of the character which has similar nature to Klana Sewandana that is told by the puppeteer. The switch of character does not experience any challenge since the character switch between Panji and Purwa is often switched. For example, if one masked puppet group is asked to perform Purwa story, then the mask of Panji is still used and worn as the mask of Panji Asmarabangun that is used to perform the character of Harjuna, Panji Kartolo to perform the character of Bima, and Raden Gunungsari to perform the character of Samba. This shows the adaptive way of thinking had by the masked puppet stakeholders in Malang regency.

In relation to the Murwakala story, the puppeteers had created the mask of Batara Kala, even one of the puppeteer has 
had the sacred mask of Batara Kala. It is wrapped in white cloth and is surrounded by offerings, especially every Thursday night. The tradition providing offering surrounded the mask has been a tradition of Javanese people since the fifth century, known as the spiritual tradition of Hinayana (Holt, 2000, p.35).

The character of Batara Kala itself physiognomically adopts the character of Sabrang; round face, round eye, hooked nose, eyebrow in balarak sineret ngombak form, thick mustache (kepelan), singobarong style in the mouth and lips, and suing prengesan for the teeth. The physiognomy characteristics of the character illustrate a rough and destructive nature. Kala means time. The society of Duwet villege themselves understands the character as sangat (the proper time), naas (danger/ bad luck), or kala (time/ change of the year). For Javanese people, the presence of kala brings complication in deciding sangat since the naas always moves in every change of the year. Therefore, every person is hoping to live in the middle position or pancher. The middle position or pancer in the social life of villagers is placed by the elders or kamituwa. In the past, the position of kamituwo or the elders was as a mediator between the villagers and dhanyang or the spirit lived in pundhen desa.

\section{The Function of Adaptation in Ruwatan}

The observation results in the assumption that decision of the host to hold ruwatan ritual is an adapted form of Javanese spiritual culture. The host of ritual believes that an action has to be expres- sed. There are two aspects lying under the host's consideration. The first is to obtain the statement or social expression from by the society that the host has already made an attempt to purify his child (Soedarsono, 1985, p. 12) and the second is to create social stability for avoiding fluctuation within the society since they feel restless believing that they have a bad luck or unfortunate kids in their village.

In addition, Javanese spiritual adaptation is also found in the content or substance of the story which believes that the existence of the ancestor spirit can be given in both good and bad luck. The Kejawen belief held by the villagers of Duwet sees that spirit has to be taken care of for them to keep peaceful, stable and balance to live around the society. In order to have a stable and tranquil condition, the human is not allowed to do disorder action. This belief is illustrated by the disorder action of Sanghyang who cannot hold his own lust that in the end creates harm.

A ruwatan ritual that is believed by people in Duwet village as a means to avoid bad luck and danger by using masking puppets as a medium has shown the symbol exchange as an adapted form. The details are presented in Table 1.

Table 1 shows the adaptation of characters of the masked puppet in its relation to the ancient belief held by Javanese society, kejawen. Panji Asmarabangun in Murwakala story does not appear since he acts as the elder (kamituwa), placing himself in the position of Deva Shiva or Sanghyang Giri Nata, king of the Gods in Nirvana. He is the symbol of power in the

Table 1. Adaptation of Character in Masked Puppet, Wayang Purwa, Custom Organization, and Ancient Belief

\begin{tabular}{|c|c|c|c|}
\hline \multicolumn{3}{|c|}{ Adaptation of Character } & \multirow[b]{2}{*}{ The Ancient Belief } \\
\hline $\begin{array}{l}\text { The Masked Puppet } \\
\text { Character }\end{array}$ & $\begin{array}{l}\text { The Charac- } \\
\text { ter of Gods }\end{array}$ & $\begin{array}{c}\text { The Character of } \\
\text { Custom Organization }\end{array}$ & \\
\hline Panji Asmarabangun & Siwa & Kamituwa & $\begin{array}{c}\text { Dhayang } \\
\text { (The Guardian Spirit) }\end{array}$ \\
\hline Klana Sewandana & Bhatarakala & Dukun (Shaman) & $\begin{array}{l}\text { Dark Power } \\
\text { Evil Spirit }\end{array}$ \\
\hline Raden Gunungsari & Wisnu & Dalang (Puppeteer) & Shaman \\
\hline
\end{tabular}


upper world. Panji Asmarabangun in everyday life lives in the position of the elders or Kamituwa who has a special duty to protect society, the keeper of the village. In the spiritual world, Panji Asmarabangun lives in pundhen desa and serves as the village keeper, as well as danyang dhesa or the villagers' gurdian.

The position of Raden Gunungsari is as the pangruwatan puppeteer. Thus, the position of Raden Gunungsari in the spiritual life is a representation of a pangruwat puppeteer that is adapted from the character of Deva Vishnu, the protector or a guardian in an ancient belief of Javanese people. Javanese people adapt the messianic understanding, or the embodiment of a savior, a protector of the society from evil and satanic spirit. It is believed that Raden Gunungsari who stays in Padepokan Gunungukir always comes down the hill to help society with social rehabilitation. The manifestation of an ancient Javanese community of shaman which in the Javanese society is also known as penggambuh. The shamans tell their ancestors' stories to their descendents and later the function is illustrated in the ability of the puppeteers in doing performing arts. Here, a connection is found. It tells that Raden Gunungsari has a magic power to repel bad spirits known as Kitab Gambuh which he got from Bali. Therefore, it can be inferred that one duty of a penggambuh is to repel the bad spirits possessing the jaranan dancers.

If the story of Murwakala in Malang Regency's musked puppet is studied, the position of a puppeteer is given to the one who have the ability to perform ruwatan ritual. The position of pangruwatan sukerto puppeteer in masked puppet can be aligned with the position of Deva Vishnu who has the authority or power to protect the universe. Meanwhile, Deva Shiva or Sanghyang Jagad Nata has the power to control and protect kayangan kadewatan. He is worshiped as the King of every God (Poerbatjaraka, 1986, p. 110). The position of Sanghyang Guru can be identified as the authority had by the village guardian or widely known as dhanyang desa. The posi- tion dhanyang desa is also aligned with the position of kamituwa who has the authority above community which means the ability to serve as mediator between upper and below world in prosper the live of society.

In 1950s, ruwatan sukerta with masked puppet as the medium was done by a masked puppet group named Asmarabangun from Kedungmangga village. Leader of the art group was usually asked to perform ruwatan sukerta. At that time, a famous puppeteer named Rasimen, or well known as Mbah Tajem had a supernatural power to actually perform ruwatan.

In the 1960s, there were still plenty of people who felt sure of a masked puppeteer named Tirtowinata and then Kangsen and some chosen people from several villages in southern part of Malang regency, from Pakisaji, Sumberpucung, to Pijiombo and Kawi mountain slope soon after that (Interview, June 6, 2015).

Belief of society related to the use of masked puppet as ruwatan medium is under main consideration that is no other that the spiritual power of the puppeteer himself. Not all masked puppeteers have the ability to perform the ritual. The criteria of becoming ruwat puppeteer are related to several factors, like, inheritance factor. It is believed that if one has the blood of a ritual puppeteer then he can be ritual puppeteer, so does one who has teacher that can perform the ritual then one can perform the ritual as well. However, the way of being a ritual puppeteer is not as smooth as only becoming the descendants. There are also some other requirements to be fulfilled. But, the genetic factor is the most important one. It is believed that there will be a major disaster if one is performing ritual without having any parents or teachers that were actually a ritual puppeteer as a background. A puppeteer from Lowong village, Pakisaji district who had not had any descendants background did the ritual, one day, and he ended up dying not long after the rituals.

Duty had by a ritual puppeteer is hard, not every puppeteer has privileges to perform it. Besides, the fee is someti- 
mes not washed. Therefore, extra sacrifice is needed to perform the ritual. A puppeteer once told a researcher that the risk he has to face is not washed with the fee that he will receive (Interview, March 5, 2015). In addition, the society also believes that the ritual results will bring impact to the health of the person who receives the ritual (Rahanto, 2013). This reason also causes fear to some puppeteers. Therefore, support from the society is needed during the ritual is performed. The society is gathered during the ritual not only to enjoy the show, but also to pray. The pray is delivered to the ritual as well as the puppeteer. Here, the society has a special role that is to give blessings and to support the puppeteer and not to mention for the person who receives the ritual to be prayed for his future life, that he can live like normal people. By doing so, it is hoped that the ritual will be a great success. In the end, the ritual symbolizes that belief is not naturally personal. By doing ritual, people are gathered and took part in a sacred event.

\section{CONCLUSION}

Ruwatan is a symbol of disorder behavior illustrated by an inappropriate behavior done by Sanghyang Makmaya and its liberation effort done by Deva Vishnu. The inappropriate behavior has to be rejected. One who did inappropriate behavior keep doing bad things had to be released from bad spirit influence through tolak bala ritual. Masked puppet here is used as a medium to help people to get into the dramatic situation. The manifestation of Batara Kala character is adapted from the form of shadow puppet purwa which purposes is to give an actual illustration for the common people. By doing so, people can actually feel the existence of bad spirits. This, in addition, may become a way to visualize a spoken story or fairy tale in a form of masked puppet. At the point of three-dimensional manifestation, the human ability level shows how human imagination shifts to a more rational way.

In addition, the adaptation of mus- ked puppet character in the process of ruwatan ritual is seen from the perspective of performance and Javanese spiritual belief. Thus, during the rituals, some Panji and Mahabarata characters are shown. For example, In the puppet story of Murwakala, there are the characters of Panji Asmarabangun as the puppeteer, Raden Gunungsari as Vishnu, and Bhatarakala as Shiva. Strong relation which is believed as pundhen by Javanese society is Kamituwa, and the guardian spirit who is the dhayang desa. The traditional belief held by society related to masked puppet aims at inviting society to gather together in living the sacred ritual.

\section{ACKNOWLEDGEMENTS}

A sincere gratitude is given to: (1) Moch. Soleh Adipramana, the leader of Padepokan Seni Mangundharmo Tumpang; (2) Mulyono, resident of Duwet Village for the opportunity given to researchers to conduct observation; (3) Sumantri (Composer of Gendhing Tayub Malang), Tri Handaya (Leader of Masked Puppet Asmarabangun-Kedungmangga performing art group), and Supardjo (The Group Leader of Masked Puppet Wirabakti-Jabung).

\section{REFERENCES}

Holt, C. (2000). Melacak Jejak-Jejak Perkembangan Seni di Indonesia. (Translated by Sudarsono). Bandung: Masyarakat Seni Pertunjukan Indonesia.

Indrawati, L. (2009). Pertunjukan Wayang Topeng Malang Sebagai Medium dalam Ritual Ruwatan. Media, Seni, dan Desain. Malang: Jurusan Seni dan Desain.

Koentjaraningrat. (1981). Antrolopogi Sosial. Jakarta: Dian Rakyat.

Kusmayati, H. (2013). Bahasa Ungkap Pemangku Kepentingan. Dialektika Seni dalam Budaya Masyarakat. Yogyakarta: Badan Penerbitan ISI Yogyakarta.

Lestari, W. (2011). Ruwatan (Merti Desa) Masyarakat Gunungkidul Pasca Gempa Bumi Tektonik di Daerah 
Istimewa Yogyakarta (Ruwatan of Gunungkidul Society After Tectonic Earthquake In Special Province of Yogyakarta). Harmonia: Journal of Arts Research and Education, 7(3). doi:http:/ / dx.doi.org/10.15294/ harmonia.v7i3.726

Lestari, W. (2014). The Philoshopy of Puppet Characters Bathara in Murwakala Play for The Value of Leadership Ethics. Harmonia: Journal of Arts Research and Education, 14(1), 8-15. doi:http:/ / dx.doi.org/10.15294/ harmonia.v14i1.2785

Mariasa, I. (2015). Taksu and Pangus As An Aesthetic Concept Entity of Bali Dance (A Case Study of Topeng Tua Dance). Harmonia: Journal of Arts Research and Education, 15(2). doi:http://dx.doi.org/10.15294/ harmonia.v15i2.4557

Muljana, S. (1979). Negarakertagama dan Tafsir Sejarahnya. Jakarta: Bhratara.

Murgiyanto, S., \& Munardi, A. M. (1978). Topeng Malang. Jakarta: Proyek Sasana Budaya. Direktorat Jendral Kebudayaan, Departemen Pendidikan dan Kebudayaan.

Poerbatjaraka. (1968). Tjerita Pandji dalam Perbandingan. Jakarta: Gunung Agung.

Poespoprodjo. (2004). Hermeneutika. Bandung: Pustaka Setia.

Poloma, M. M. (2010). Sosiologi Kontemporer. Jakarta: Raja Grafindo Persada.

Probonegoro, N. K. (2008). Ritus Ruwat: Esensialisme Baru dalam Politik Kebdayaan Indonesia. Jurnal Ma-

Susanti, S. (2011). FILSAFAT SENI: ANTARA PERTANYAAN DAN TANTANGAN (Philosophy of Art : Between Question and Challenge). Harmonia: Journal Of Arts Research And Education, 1(2). doi:http://dx.doi.org/10.15294/ha rmonia.v1i2.840

Sunarto. (2011). TUGAS ILMU PENGETAHUAN DAN SENI DALAM ERA INFORMASI (The Duties of Science and Art in the Information era). Harmonia: Journal Of Arts Research And Education, 2(3). doi:http:/ / dx.doi.org/10.15294/ha rmonia.v2i3.856
Sunarto. (2013). KESADARAN ESTETIS MENURUT HANS-GEORG GADAMER (1990-2002). Harmonia: Journal Of Arts Research And Education, 11(2). doi:http://dx.doi.org/10.15294/har monia.v11i2.2212

Suharto. (2011). Refleksi Teori Kritik Seni Holistik : sebuah Pendekatan Alternatif dalam Penelitian Kualitatif bagi Mahasiswa Seni (Reflection on Art Criticism and Holistic Art Criticism : an Alternative Approach of Qualitative Research for Art Students).

Harmonia: Journal Of Arts Research And Education, 8(1).

doi:http://dx.doi.org/10.15294/har monia.v8i1.803

Suharto.(2013).Hari Musik Nasional, Lalu? Gagasan, Universitas Negeri Semarang, 13

Zaenuri, A. (2011). Estetika

Ketidaksadaran: Konsep Seni menurut Psikoanalisis Sigmund Freud (1856-1939) (Aesthetics of Unconsciousness: Art Concept according Sigmund Freud Psychoanalysis). Harmonia: Journal Of Arts Research And Education, 6(3).

doi:http://dx.doi.org/10.15294/har monia.v6i3.811

Malarsih, -. (2011). Seni Postmodern dalam Wujud Konkretnya (Postmodern Art in a Concrete Form). Harmonia: Journal Of Arts Research And Education, 6(3). doi:http://dx.doi.org/10.15294/har monia.v6i3.815

Suryani, S. (2014). Tayub as a Symbolic Interaction Medium in Sedekah Bumi Ritual in Pati Regency. Harmonia: Journal Of Arts Research And Education, 14(2), 97-106. doi:http://dx.doi.org/10.15294/har monia.v14i2.3291

Suharto, S. (2011). Refleksi Teori Kritik Seni Holistik : sebuah Pendekatan Alternatif dalam Penelitian Kualitatif bagi Mahasiswa Seni (Reflection on Art Criticism and Holistic Art Criticism : an Alternative Approach of Qualitative Research for Art Students). Harmonia: Journal Of Arts Research 
And Education, 8(1).

doi:http:/ / dx.doi.org/10.15294/har

monia.v8i1.803

Mariasa, I. (2015). Taksu and Pangus As An Aesthetic Concept Entity of Bali

Dance (A Case Study of Topeng Tua Dance). Harmonia: Journal Of Arts Research And Education, 15(2). doi:http:/ / dx.doi.org/10.15294/har monia.v15i2.4557

Hapsari, L. (2014). FUNGSI TOPENG

IRENG DI KURAHAN

KABUPATEN MAGELANG.

Harmonia: Journal Of Arts Research And Education, 13(2).

doi:http:/ / dx.doi.org/10.15294/har monia.v13i2.2780 syarakat dan Budaya, 10(1), 1-26.

Rahanto, S. (2013). Pengaruh

Ruwatan ter-

hadap Kesehatan. Buletin Penelitian

Sistem Kesehatan, 15(3), 282-288.

Ritzer, G. (2009). Sosiologi Ilmu Pengetahuan Berparadigma Ganda. Jakarta: Raja Grafindo Persada.

Rusdy, S. T. (2010). Ruwatan Sukerta E Ki Timbul Hadiprayitno. Jakarta: Yayasan Kertanegara.

Soedarsono. (1985). Peranan Seni Budaya dalam Sejarah Kehidupan Manusia Kontinuitas dan Perubahannya, Naskah Pidato (tidak diterbitkan) Pengukuhan Jabatan Guru Besar pada Fakultas Sastra, Universitas Gadjah Mada: Yogyakarta.

Soerjo, D. (1985). Gaya Hidup Masyarakat Jwa di Pedesaan Pola Kehidupan Sosial-Ekonomi dan Budaya. Yogyakarta: Proyek Penelitian dan Pengkajian Kebudayan Nusantara. Direktorat Pendidikan dan Kebudayaan. Gajah Mada Yogyakarta.

Suanda, T. A. (2009). Tari Topeng Cirebon, Jurusan Tari STSI Bandung: Bandung

Sunarto. (2009). Wayang Kulit Purwa: Dalam Pendangan Sosio-Budaya. Yogyakarta: Arindo Nusa Media.

Suyanto. (2002). Wayang Malangan. SurakartaL Citra Etnika.

Tjintariani. (2013). Ruwatan Masal melalui Pergelaran Wayang Kulit. Harmonia: Journal of Arts Research and Education, 12(1). doi:http://dx.doi. org/10.15294/harmonia.v12i1.2214 